Howard University

From the SelectedWorks of Ezer Kang

2015

Human Immunodeficiency Virus (HIV) Stigma: Spoiled Social Identity and Jürgen Moltmann's Trinitarian Model of the Imago Dei

Dr. Ezer Kang, Howard University 


\title{
Human Immunodeficiency Virus (HIV) Stigma: Spoiled Social Identity and Jürgen Moltmann's Trinitarian Model of the Imago Dei
}

\author{
Ezer Kang \\ Wheaton College, USA \\ ezer.kang@wheaton.edu
}

\begin{abstract}
Recent scholarship has conceptually reframed HIV-related stigma as a social rather than individual process that perpetuates and sustains relations of power that devalues persons living with HIV (PLHIV). If HIV-stigma is perpetuated by social relationships that are embedded in socio-economic and political structures that insidiously exclude PLHIV, and less by 'spoiled' individual identity, how does the widely referenced doctrine of the imago Dei inform efforts to mitigate structural forms of HIV-stigma? This paper examines Jürgen Moltmann's trinitarian model of the imago Dei which suggests that humanity bears the image of the mutually supporting persons of the Trinity. A relationship that is characterized by radical equality that fosters participation in all facets of suffering - an impetus set by the hope established by Christ's resurrection. It is this divine imago that incites the church to deliberately contradict identities that are spoiled by HIV with one that is of dignity and hope.
\end{abstract}

\section{Keywords}

HIV - AIDS - Stigma - Jürgen Moltmann - imago Dei

\section{Introduction}

Stigma is 'a social process or personal experience characterized by exclusion, rejection, blame or devaluation that results from experience or reasonable 
anticipation of an adverse social judgment about a person or group.' ${ }^{1}$ Framed as an individually constructed trait, early scholarship on human immunodeficiency virus (HIV) stigma has largely focused on stereotype formation and its behavioral and emotional consequences. Recent scholarship, however, has conceptually reframed HIV-related stigma as a social rather than individual process that perpetuates and sustains relations of power that excludes and devalues people and groups. Stigma produces and perpetuates existing 'relations of power and control' that marks groups most vulnerable to HIV (e.g., women, men who have sex with men [MSM] of colour, and injection-drug users.$^{2}$ As such, the focus of scholarship has shifted from examining how individuals act towards one another to how culture and history breed inter-group differences and domination that perpetuate HIV and AIDS-related stigma. Researchers have therefore challenged stigma-reduction interventions that focus on individual behavior and attitudinal changes and argued for structural interventions aimed at shifting social scripts about HIV and how it intersects with other causes of inequalities based on (but not limited to) class, gender, race, or sexual identity.

Ecclesial postures of compassion towards persons living with HIV (PLHIV) have largely been informed by an inarguable notion that dignity and worth are bestowed on PLHIV because of the imago they individually bear of the Creator. The doctrine that human beings are created in the imago Dei has gained considerable attention because of how it bears on issues of human dignity in contemporary society. This popular framing of the imago Dei, in other words, has been formative in developing faith-based initiatives aimed at reducing stigmatization of PLHIV. However, if HIV-stigma is indeed perpetuated by social structures and hierarchies, and less by 'spoiled' individual identity, does the doctrine of the imago Dei adequately inform church-based HIV initiatives, while remaining faithful to Scripture and tradition?

This article examines Jürgen Moltmann's conceptualization of the imago Dei. Moltmann argues that we express our individual worth and dignity as bearers of God's image in relationship with God. Because God is in relationship with humanity in the present world, the image of God is recognized in our relationship with one another. Bearing the likeness of God is not simply an intrinsic reality, rather a social one that is actualized in social relations.

1 Mitchell Weiss and Jayashree Ramakrishna, 'Stigma Interventions and Research for International Health', Lancet, 367 (2006), 536-38 at 536 .

2 Richard Parker and Peter Aggleton, 'HIV and AIDS-Related Stigma and Discrimination: A Conceptual Framework and Implications for Action', Social Science and Medicine, 57 (2003), $13-24$ at 16. 
As such, what are implications of Moltmann's social framing of the imago Dei for structural interventions aimed at mitigating the adverse effects of HIV stigma?

To address this question, I first review select studies in public health and community psychology that investigate HIV-related stigma as experienced by persons living with HIV illness - with a particularly focus on structural forms of stigma. Secondly, I examine how Moltmann's social trinitarian theology and narrative of the cross were instrumental in shaping his doctrine of the imago Dei. Thirdly and finally, I propose how Moltmann's model of the imago Dei provides a practical direction for the contemporary church to creatively and prophetically mitigate the exclusionary scourge of stigma and to move towards embracing and standing in solidarity with persons living with HIV.

\section{HIV Stigma as Spoiled Identity}

Drawing from his well-referenced work with persons with persistent mental illness and physical deformities, Goffman (1963) defined stigma as a socially discrediting or deviant mark that renders a person's identity 'spoiled' by society at large. ${ }^{3}$ In the context of H IV illness, stigma is a judgment that is conferred on someone based on his or her HIV-seropositive status. One's HIV-seropositive status is socially attached to negative stereotypes of PLHIV as separate from and of lowered status, and consequently a legitimate target of discrimination. ${ }^{4}$ Many inferred from Goffman's notion of a spoiled identity that stigma was an individually possessive constructed trait. As such, early research on HIV stigma focused on stigmatized perception of individuals, stereotype formation and its behavioral and emotional consequences. Studies, for example, have identified two categories of stigmatization-enacted and felt stigma, distinguished by experiences of actual discrimination (enacted stigma) and one's perceived fear of encountering stigmatizing practices (felt stigma). ${ }^{5}$ Both forms of HIVrelated stigma are entwined with the illness' course and uniquely sustained or mitigated by the responses of broader society, friends, and families. Moreover, there are multiple layers of stigma particularly among women, and ethnic and

3 Ervin Goffman, Stigma: Notes on the Management of a Spoiled Identity (New York: Simon \& Schuster, 1963).

4 Bruce Link and Jo C. Phelan, 'Conceptualizing Stigma', Annual Review of Sociology, 27 (2001), $363-85$.

5 Graham Scrambler and Anthony Hopkins, 'Generating a Model of Epileptic Stigma: The Role of Qualitiative Analysis', Social Science and Medicine, 30 (11), 1187-94. 
sexual minorities living with HIV. Perceptions of marginalization and social rejection, for example, could be perpetuated by virtue of one's serostatus, risk behaviors associated with HIV transmission, undocumented immigration status, gender, or sexual orientation. The immediate consequence of enacted HIV-related stigma is a loss or diminution of individual status. PLHIV who experience status loss often report poor mental health outcomes (for example, depression, negative self-worth, social isolation), delayed access to and inconsistent utilization of HIV medical care, poor antiretroviral medication adherence, and avoidance of serostatus disclosure, particularly among racial and ethnic minorities in the United States and groups that contend with inequalities that predate their HIV diagnosis. ${ }^{6-7}$

PLHIV commonly develop a heightened 'stigma consciousness' which informs their world view and behaviour. ${ }^{8}$ Specifically, they vigilantly avoid situations that place them at risk for repeated discrimination on account of their HIV-serostatus. They maintain their illness as a secret within public and personal social networks-a task that becomes a consuming priority. The emotional demand of sustaining this heightened sense of vigilance or awareness of social devaluation often has more deleterious effects than the immediate consequences of a discriminatory event. As such, the social setting in which stigma is perceived and experienced influences the degree of psychological toll on PLHIV.

An important dimension of HIV stigma to consider is pubic fear of HIV contagion - one that is shaped and reinforced by ingrained misconceptions of HIV transmission or unfamiliarity with the epidemic. Stigma in rural China, for example, is largely enacted by excluding and isolating PLHIV out of fear of infection and not necessarily motivated by socio-moral condemnation of HIV risk behaviour. In some regions, the inclination to avoid social contact with PLHIV may reflect more instinctual self-preservation rather than a malicious intent to discredit another. ${ }^{9}$ Although overt expressions of HIV-related stigmatization in the United States have declined since the 1990s, many people

6 Ezer Kang, Bruce Rapkin, and Chrystianne DeAlmeida, 'Are Psychological Consequences of Stimga Enduring or Transitory? A Longitudinal Study of HIV Stigma and Psychological Distress among Asians and Pacific Islanders Living with HIV Illness', AIDS Patient Care and STDS, 20:10 (2006), 712-23.

7 Ezer Kang et al., 'Multiple Dimensions of HIV Stigma and Psychological Distress among Asians and Pacific Islanders Living with HIv Illness', AIDS \& Behavior, 9:2 (2005), 145-54.

8 Link and Phelan, 'Conceptualizing Stigma', 374.

9 Rui Deng et al., 'Drug Abuse, HIV/AIDS and Stigmatisation in a Dai Community in Yunnan, China', Social Science and Medicine, 64 (2007), 1560-71. 
continue to have misinformed fears of HIV transmission by casual social contact and punitive and negative attitudes towards PLHIV. ${ }^{10}$ Similarly, in rural regions of East Asia, illness stigma is based largely on misconceptions of casual HIV transmission coupled with cultural proscriptions against groups at higher risk for HIV infection (for example, injection drug users).

\section{HIV Stigma as Power and Exclusion}

Recent scholarship has reframed HIV-related stigma as a structural as well as an individual process that perpetuates and sustains relations of power that exclude and devalue people and groups. Bonilla-Silva's (1997) conceptualization of structure in the context of how race, gender, and social class intersect to perpetuate inequalities experienced by racial minorities in the United States is helpful to consider. He references structure as 'organizing principles on which sets of social relations are systematically patterned' and argued that specific practices and social relations reify a majority 'dominant race to institutionalize its dominance at all levels of society. ${ }^{11}$ Drawing from Bonilla-Silva's conceptualization of structure, Hatzenbuehler and Link (2014) define structural stigma more specifically as 'societal-level conditions, cultural norms, and institutional policies that constrain the opportunities, resources, and well-being of the stigmatized. ${ }^{12}$ The formation and impact of these structural forces are often invisible to those who wield power. As such, structural interventions operate at socio-political levels to change social conditions that undergird and perpetuate stigma. ${ }^{13}$ This approach shifts the focus from how individuals act towards another to how culture and history construct social hierarchies and breed inter-group difference and domination that perpetuate the marginalization of PLHIV. As such, researchers have challenged conventional individual-level interventions (for example, cognitive-behavioral therapy, motivational-interviewing) and argued for structural interventions aimed at shifting community scripts about HIV and how it intersects with forms of socio-cultural hegemony.

10 Gregory Herek et al., 'H IV-Related Stigma and Knowledge in the United States: Prevalence and Trends, 1991-1999', American Journal of Public Health, 92:3 (2002), 371-77.

11 Eduardo Bonilla-Silva, 'Rethinking Racism: Toward a Structural Interpretation', American Sociological Review, 62:3 (1997), 465-80 at 465 .

12 Mark Hatzenbuehler and Bruce Link, 'Introduction to the Special Issue on Structural Stigma and Health', Social Science and Medicine, 103 (2014), 1-6 at 2.

13 Jonathan Cook et al., 'Intervening Within and Across Levels: A Multilevel Approach to Stigma and Public Health', Social Science and Medicine, 103 (2014), 101-09. 
Notable examples of structural interventions are mass media programming and public health education that dispel fears of interacting with PLHIV and challenge perceptions that further marginalize groups at higher risk for HIV transmission (e.g., MSM, injection-drug users). Religious systems have also been more widely studied as a social force that shapes cultural and institutional responses to HIV/AIDS. Religious ideologies and practices have played a significant role in creating, reinforcing, and challenging diverse responses to HIV prevention and care. ${ }^{14}$ This, for example, has informed studies in the United States that examine the unique roles of key community institutions such as African American and Chinese ethnic churches in re-shaping cultural narratives about HIV prevention in their respective communities. ${ }^{15-16}$ Historically, churches and religious institutions have also wielded power by distinguishing those who are inside or outside the fellowship of believers, and in doing so engage in a dynamic of 'othering' that distances PLHIV and keeps them at the margins. Van Breda further proposes that 'othering in the name of God is the supreme form of oppression. ${ }^{17}$

Despite the recent shift of attention to structural dimensions of stigma, it would be misleading to suggest that structural and individual stigma are mutually exclusive as concepts. Link and Phelan (2001) argue for the importance of recognizing the multidimensionality of stigma and how the confluence of different components results in the unfolding of stigma. ${ }^{18}$ Specifically, society first distinguishes and labels human differences based on social, economic and cultural scripts. These labelled differences are then linked to undesirable characteristics that form stereotypes (for example, HIV is contagious and can be transmitted through casual contact). The third component of the stigma process becomes evident when socially constructed labels mark a divide that separates the stigmatized from broader society. This division creates and perpetuates a loss of status or a downward social placement, which cultivates

14 Miguel Múnoz-Laboy et al., 'Religious Responses to HIV and AIDs: Understanding the Role of Religious Cultures and Institutions in Confronting the Epidemic', Global Public Health, 6:S2 (2011), S127-S31.

15 Ezer Kang et al., 'Influences of Stigma and HIV Transmission Knowledge on Member Support for Faith-Placed HIV Initiatives in Chinese Immigrant Buddhist and Protestant Religious Institutions in New York City', AIDS Education and Prevention, 25:5 (2013), $445^{-5} 6$.

16 John Chin et al., 'Service Delivery for Asians and Pacific Islanders Living with HIV/AIDs: Challenges and Lessons Learned', Journal of Health Care for the Poor and Underserved, 17(2006), 910-27.

17 Adrian Van Breda, 'Stigma as 'Othering' among Christian Theology Students in South Africa', Journal of Social Aspects of HIV/AIDS, 9:4 (2012), 181-91 at 189. Link and Phelan, 'Conceptualizing Stigma', 367. 
both overt and subtle forms of discrimination against persons who are labelled. Finally, Link and Phelan propose that the enactment of stigma necessitates the practice of social, economic, and political power-in other words, one cannot stigmatize unless one wields some form of power over others.

Recent scholarship has in fact found evidence for a synergistic and continually evolving relationship between individual and structural stigma such that one interacts with the other to influence health behaviours among stigmatized groups. ${ }^{19}$ Earnshaw and her colleagues (2013) propose that strengthening economic and community empowerment and trust at a structural level creates common in-group identities that promote meaningful contact with PLHIV. ${ }^{20}$ This in turn enhances social support and adaptive coping which then lowers societal HIV stigma. In African countries with high HIV prevalence, for example, policy interventions such as universal access to antiretroviral therapy, ${ }^{21}$ provision of Voluntary HIV Counseling and Testing (VCT), ${ }^{22}$ poverty alleviation interventions ${ }^{23}$ were associated with less fear of publically disclosing one's HIV serostatus and less discriminatory attitudes towards PLHIV. Mass media campaigns and educational interventions have also been effective means of challenging public fear of casual HIV transmission. ${ }^{24}$ In Malawi, for example, a national mass media campaign that featured the lives of PLHIV coupled with community mobilization for HIV-antibody testing resulted in a significant association between programmed exposure and espousing less stigmatizing attitudes towards PLHIV, which in turn was associated with increased public HIV testing. ${ }^{25}$ These examples provide a compelling rationale for conceptualizing HIV stigma within a syndemic framework-a concept

19 Gilbert Gee, 'A Multilevel Analysis of the Relationship between Institutional and Individual Racial Discrimination and Health Status', American Journal of Public Health, 92 (2002), 615-23.

20 Valerie Earnshaw et al., 'Stigma and Racial/ Ethnic Hiv Disparities: Moving Towards Resilience', American Psychologist, 68:4 (2013), 225-36.

21 William Wolfe et al., 'The Impact of Universal Access to Antiretroviral Therapy on HIV Stigma in Botswana', American Journal of Public Health, 98:10 (2008), 1865-71.

22 Maria Roura et al., 'Scaling up Stigma? The Effects of Antiretroviral Roll-out on Stigma and HIV Testing. Early Evidence from Rural Tanzania', Sexually Transmitted Infections, 85 (2009), 308-12.

23 Alexander Tsai et al., 'Harnessing Poverty Alleviation to Reduce Stigma of HIV in SubSaharan Africa', PLoS Med, 10:11 (2013), e1001557.

24 Stella Babalola et al., 'Media Saturation, Communication exposure and HIV Stigma in Nigeria', Social Science and Medicine, 68 (2009), 1513-20.

25 Sima Berendes and Rajiv Rimal, 'Addressing the Slow Uptake of HIV Testing in Malawi: The Role of Stigma, Self-Efficacy and Knowledge in the Malawi Bridge Project', Journal of the Association of Nurses in AIDS Care 22:3 (2011), 215-28. 
borrowed from epidemiological studies and broadly defined as a 'set of meshed and mutually enhancing health problems that, working together in a context of deleterious social and physical conditions that increase vulnerability, and significantly affect the overall disease. ${ }^{26}$ How do we apply a syndemic lens to understanding the role of faith-based institutions in HIV care and prevention programming?

With the timely emergence of faith-based HIV programming, Christians have increasingly referenced the imago Dei as a theological rationale for enacting Christ's compassion towards PLHIV. Living with HIV cannot diminish a person's inherent worth because humanity bears the divine image. This accessible doctrine, for example, has effectively mobilized ministries that prepare and deliver meals to homebound PLHIV, organize hospital visitations, collect unused antiretroviral medications to stock the empty shelves of HIV clinics, or commissioning medical students to serve on short-term mission trips to HIV clinics. In addition to these vital acts of compassion, how can the church also consider means of addressing broader structural precipitators of stigma attached to PLHIV? To what extent does the doctrine of the imago Dei help frame our understanding and motivation for this shift? To begin addressing these questions, we will first consider how the imago Dei is traditionally understood.

\section{Imago Dei as Individual Image}

The doctrine that humans were created in the imago Dei has been widely referenced by faith-based groups who uphold and advocate for the sacredness, dignity, ${ }^{27}$ honour ${ }^{28}$ and worth ${ }^{29}$ of PLHIV. This basic theological tenet can be traced to the foundational scriptural text-'So God created humankind in his image, in the image of God he created them; male and female he created them' (NRSV, Gen. 1:27). Humanity created in God's image implies that God places

26 Merrill Singer, 'Pathogen-Pathogen Interaction: A Syndemic Model of Complex Biosocial Processes in Disease', Virulence 1:1 (2010), 10-18 at 15.

27 David Hodge and Terry Wolfer, 'Promoting Tolerance: The Imago Dei as an Imperative for Christian Social Workers', Journal of Religion and Spirituality in Social Work, 27:3 (2008), 297-313.

28 Johan Bouwer, 'Human Dignity and HIV/AIDs', Scriptura: International Journal of Bible, Religion and Theology in Southern Africa, 95 (2007), 262-8.

29 Elias Bongmba, Facing a Pandemic: The African Church and the Crisis of HIV/AIDS (Waco: Baylor University Press, 2007). 
humanity in unique standing from other creatures. Adam and Eve's special relationship with God in the Garden of Eden imbued a dignified status that marked humanity from all other creation.

Despite being well referenced within popular ecclesial circles, it is noteworthy that the imago Dei is explicitly referenced in only three Old Testament texts (Gen. 1:26-27; 5:1; and 9:6). In the New Testament, God's likeness in humans is referenced in three texts (1 Cor. 11:7; Jas. 3:9; Rom. 8:29). The scarcity of biblical references has led to diverse perspectives on the meaning of humanity created in God's likeness and its application to inclusionary or exclusionary practices towards PLHIV. ${ }^{30}$

In Facing a Pandemic: The African Church and the Crisis of HIV/AIDS (2007), for example, Elias Bongmba portrays the human body as an HIV carrier, and argued that 'the body is sacred and bears the imago dei ... that the virus cannot take away one's sense of self and dignity. 31 This serves as a clarion call for the global Christian community to practice an ethic of compassion and care that uphold human worth even as the bodily host for HIV deteriorates. Moreover, given the escalating rates of HIV infection among women, Bongmba contends that 'God made no distinctions about the quality and quantity of the divine image deposited in male and female,' and therefore there is no theological justification for gender-based discrimination that further diminishes the worth of women living with HIV. ${ }^{32}$ The divine imago was an intrinsic mark of humanity that is internally borne-a sine qua non to human dignity that Christians are called to uphold.

The divine imago also articulates a shared humanity that strives to narrow the divide between persons living with and without the virus. HIV is not simply a reality that lies beyond ecclesial margins - rather it is argued that the contemporary church or the body of Christ is inflicted with AIDs as well. ${ }^{33}$ The epidemic therefore leaves no member of the church unscathed, and if one member suffers then all suffer. Moreover, a shared divine image undergirds solidarity among churches in North America and Africa, where HIV/AIDs has left a disparate mark. In other words, HIV/AIDS is not an exclusive African problem that the Western church deems irrelevant. The supposition that humanity

30 J. Richard Midddleton, The Liberating Image: The Imago Dei in Genesis 1 (Grand Rapids: Brazo Press, 2005).

31 Bongmba, Facing a Pandemic, p. 50.

32 Ibid., p. 47 (original italics).

33 Adriaan vanKlinken, 'When the Body of Christ Has AIDs: A Theological Metaphor for Global Solidarity in Light of HIV and AIDs', International Journal of Public Theology, 4:4 (2010), 446-65. 
individually bears the image of God carries well-established implications on how the global Christian community should challenge postures of exclusion and 'othering. ${ }^{34}$ By fostering empathic interactions with PLHIV and changing the praxis of our interpersonal discourse to extend respect and dignity, we begin to mitigate the effects of stigma on PLHIV.

\section{Trinitarian Persons: Underpinnings of the Imago Dei}

For Jürgen Moltmann, humanity's likeness to God (Gottebenbildlichkeit) is a theological category rather than an anthropological term. ${ }^{35}$ The German Reformed theologian challenged the conventional notion of imago Dei as an inherent human property or capacity, and alternatively proposed that the image of God resides in relationships between persons in community. This was primarily drawn from his concept of God as the community of persons of the Trinity. Notable Moltmann scholar, Richard Bauckham explains that Moltmann's idea of God 'could be said to hinge on a concept of dynamic relationality. ${ }^{36}$ In his seminal work, God in Creation (1993), Moltmann references Gen. 1:26-27 to argue that as God's image bearer, 'the human being is God's indirect manifestation on earth. To be an image of something always means letting that something appear, and revealing it.'37 What does humanity reveal? Moltmann proposes that the divine image is not an individual, but 'person with person' and therefore 'the image of God must not merely be sought for in human individuality; we must look for it with equal earnestness in human sociality. ${ }^{\prime 3}$ Stated differently, the imago Dei is not a possession of a static human characteristic or trait—but rather God's 'whole existence,' which appears in and through right human relationships-'it is these which are the image of God and his glory.'39 Volf's (2006) elaboration of imaging the Trinity is important to note, 'Because God has made us to reflect God's own triune being, our human tasks are not first of all to do as God does-and certainly not

34 Van Breda, 'Stigma as 'Othering' Among Christian Theology Students in South Africa'.

35 Jürgen Moltmann, God in Creation: A New Theology of Creation and the Spririt of God, Gifford Lectures (Minneapolis: Fortress Press, 1993).

36 Richard Bauckham, The Theology of Jürgen Moltmann (Edinburgh: T\&T Clark, 1995), p. 14.

37 Moltmann, God in Creation, p. 221.

38 Jürgen Moltmann The Trinity and the Kingdom (Minneapolis: Fortress Press, 1993), p. 199 (my italics).

39 Moltmann, The Trinity and the Kingdom, p. 221. 
to make ourselves as God is—-but to let ourselves be indwelled by God and to celebrate and proclaim what has been done, is doing, and will do. 40

In On Human Dignity (1984), Moltmann explains that the image of God resides 'in the fullness of their [human] lives and in all life's relationshipseconomic, social, political, and personal-[humans] are destined to live before the face of God, to respond to the Word of God, and responsibly to carry out their task in the work implied in their being related in the image of God. ${ }^{41}$ Scott Paeth, in his excellent analysis of Moltmann's contribution to public theology, argues that for Moltmann the mark of the imago Dei on all spheres of communal human activity implies an obligation to challenge and resist any human act of dehumanization that compromises one's rights in community. ${ }^{42}$ Therefore, mitigating the effects of HIV stigma goes beyond recognizing a person's intrinsic dignity and worth as bearers of God's image. It necessitates recognizing and advocating for economic and socio-political systems that promote and sustain equitable and just human relationships that reflect God's splendor and glory on earth.

Moltmann's reframing of the imago Dei was significantly shaped by his Trinitarian theology, which proposes that God is relationally intertwined with humanity through the Holy Spirit, such that God dwells in every individual person. His relational doctrine of the imago Dei relied on a new social model of the Trinity that stressed the relationship between the Father, Son, and Holy Spirit. For Moltmann, humans fulfill their imago Dei by participating in the fellowship between the three persons and being thereafter transfigured into this image in the context of social relationships. Rather than conceiving the likeness to God as an intrinsic quality to be realized, Moltmann reconstructs the image in terms of human relationships that mirror the Trinitarian life. Joy Ann McDougall in Pilgrimage of Love: Moltmann on the Trinity and Christian Life (2005) further suggests that for Moltmann, 'an individual's fellowship with the triune God, which expresses itself in gratitude and praise, empowers human beings to realize a visible image of that very same fellowship with other human beings in the world. 43

\footnotetext{
40 Miroslav Volf, 'Being as God Is: Trinity and Generosity', in M. Volf and M. Welker, eds, God's Life in Trinity, (Minneapolis: Fortress, 2006), pp. 3-12 at p. 6.

41 Jürgen Moltmann, On Human Dignity (Philadelphia: Fortress Press, 1984), p. 23.

42 Scott Paeth, Exodus Church and Civil Society: Public Theology and Social Theory in the Work of Jürgen Moltmann, (Burlington, VT: Ashgate Publishing Company, 2008).

43 Joy Ann McDougall, Pilgrimage of Love: Moltmann on the Trinity and Christian Life (Oxford: Oxford University Press, 2005), p. 162.
} 
Moltmann challenges the Trinitarian narrative that casts God as a monarchical ruler in history. Alternatively, he argues for a Trinitarian model that stresses the perichoresis between the Father, Son and Holy Spirit, who is present in eternal history. A christologic term referenced by John the Damascene, perichoresis depicts the triune communion as the 'circling movements of mutually indwelling that arise from the three persons' eternal acts of self-donation. ${ }^{44}$ The mutual relationship between the persons is necessarily the focus in order to highlight humanity's dignified standing in likeness of the triune God. However, Volf (1998) elaborates that perichoresis 'can be applied to human community only in analogous rather than a univocal sense' and that sin renders it impossible for human beings to reflect the perfect creaturely image of the Triune God 'which they are eschatologically destined to become.45 Therefore, consistent with Moltmann's understanding of the imago Dei is the view of God as a community of persons, rather than a monotheistic monarch. As such, the Trinity is a 'non-hierarchical community' where neither the Father, Son, nor Holy Spirit precedes each other. ${ }^{46}$ In Moltmann's view, the 'functional problem' of a single divine lordship narrative of the Trinity is reducing the Trinitarian Persons into 'mere aspects of the one subject, ${ }^{47}$ and consequently a limited appreciation of the intimate relationship between God and humanity. Moreover, he argues that the Western foci on individual autonomy and consumerist approach towards human life, leaves little room to fully appreciate the cultivation of a community defined by 'their relations with one another and in their significance for one another, not in opposition to one another, in terms of power and possession. ${ }^{48}$ On the perichoretic level, Moltmann argues for the possibility of a 'community without uniformity and a personhood without individualism.'49 He decries implications of a framework that arguably justified acts of domination and the persecution of persons and groups. Moltmann therefore resists any notions of hierarchy or subordination of persons in his trinitarian narrative. Mutual responsibility and regard in such a community imparts dignity to each individual person. Moltmann's social Trinitarian model is foundational

44 Joy Ann McDougall, 'The Return of Trinitarian Praxis? Moltmann on the Trinity and the Christian Life', Journal of Religion, 83:2 (2003), 177-203 at 186.

45 Miroslov Volf, 'The Trinity Is Our Social Program: The Doctrine of the Trinity and the Shape of Social Engagement.' Modern Theology, 14:3 (1998), 403-23 at 405.

46 Jürgen Moltmann, Experiences in Theology: Ways and Forms of Christian Theology (Minneapolis: Fortress Press, 2000), p. 317.

47 Moltmann, The Trinity and the Kingdom, p. 18.

48 Ibid., p. 198.

49 Moltmann, Experiences in Theology, p. 316. 
then for understanding humanity's uniqueness marked by the Spirit's indwelling, which is recognized in relationship with one another. Practically, perichoresis is a prescription for human community-'true human relationship is to correspond to the triune God and be his image on earth. ${ }^{50}$ Moltmann argues that the triune God's relationship with, and active current presence in the world through the Spirit is central to framing human agency, identity, and purpose in the world - 'to discover God in all the beings he has created and to find his life-giving Spirit in the community of creation they share.51

Moltmann's reframing of the imago Dei that reflects his Trinitarian theology raises the question - what is the nature of the Spirit's indwelling within us that shapes our social relationships? For Moltmann, friendship is central in describing God's relationship with humanity. Friendship is a direct relationship between humanity and God that is characterized by active engagement and mutual conversation chiefly through prayer. Moltmann's framework of friendship and opposition to depicting God as a monotheistic 'Lord of the world' however has been scrutinized. In Understanding the Imago Dei (2011), Dominic Robinson, for example, questions whether Moltmann 'clouded his notion of the God-human relationship' blurring the relational line between God and humanity and underplaying the human need for a saviour. ${ }^{52}$ Depicting God primarily as a friend grants persons freedom and dignity, but also bridges the 'distance enjoined by sovereignty' and that 'by virtue of friendship with God in the Spirit, we have the chance to influence God and to participate in his rule.53 Robinson further questions Moltmann's understanding of human depravity, and God's omnipotence and saving work fulfilled in the death and resurrection of the Son. Alan Torrance also cautions against Moltmann's 'Pelagian tendencies' in Persons in Communion (1996), questioning the extent to which Moltmann compromised the transcendence and sovereignty of God and domesticated the doctrine of sin - that God is part of the human experience to the extent that God ceases to be the God whom we revere and worship in the traditional sense. ${ }^{54}$ MacDougall raises a similar criticism contending that Moltmann's lack of robust doctrine of sin contributed to a certain utopianism

\footnotetext{
5o Jürgen Moltmann, History and the Triune God (New York: Crossroad, 1992), p. 60.

51 Moltmann, God in Creation, p. 24.

52 Dominic Robinson, Understanding the 'Imago Dei': The Thought of Barth, Von Balthasar and Moltmann (Burlington, vт: Ashgate Publishing Company, 2011), p. 141.

53 Moltmann, The Trinity and the Kingdom, p. 221.

54 Alan Torrance, Persons in Communion: An Essay in Trinitarian Description and Human Participation (Edinburgh: T\&T Clark; 1996), p. 310.
} 
in his social Trinitarian doctrine of sin that, in turn, leaves it open to the charge of impracticality. 55

While recognizing varied concerns about Moltmann's Trinitarian model morphing into forms of instrumentalism that merely serves as a contemporary social model for the church and society at-large, ${ }^{56}$ one cannot refute the import of his social Trinitarian model in challenging North American churches to respond to a host of global quandaries that contextualizes HIV-related stigma, such as poverty, resource disparities, and ethnic and gender divisions. Moltmann's social Trinitarian model expresses that challenge of how humanity's creation in God's image challenges us to live as a 'community of men and women, without privileges and subjugation. ${ }^{57}$ Such communities however are costly and approached with caution, as it entails identification and solidarity with all forms of human suffering. To address this challenge, Moltmann, in his seminal work, The Crucified God (1995) provides a framework by introducing God's loving solidarity with his creation in its suffering. It is this to which we now turn. ${ }^{58}$

\section{Trinitarian Person and the Crucified God}

When I wrote the theology of the cross, I wanted to express something that had been stirring within me for a long time: How can one speak about God in Germany after Auschwitz? I discovered my own answer in the question: How can Christians speak of God after Golgotha?59

Moltmann's formulation of the imago Dei is largely predicated on his narrative of the cross, which proposes a Triune separation-unity dialectic that centers on Christ's suffering on the cross, upon which humanity is restored to God's image. In The Crucified God (1993) Moltmann proposes that the unity between

55 McDougall, Pilgrimage of Love, p. 182. In the foreword of MacDougall's book, Moltmann wrote how his experiences at the Nazi death-camps of Treblinka and Majdanek, led him to follow 'the path of Christ's passion and his descent into hell into such depths of evil that the concepts of sin, guilt, and godlessness were struck out of my hands... Can we grasp this reality with moral and traditional theological concepts?' (Mc Dougall, Pilgrimage of Love, p. xiv).

56 Isaiah Nengean, The Imago Dei as the Imago Trinitatis: Jürgen Moltmann's Doctrine of the Image of God (New York: Peter Lang, 2013).

57 Moltmann, The Trinity and the Kingdom, p. 198.

58 Jürgen Moltmann, The Crucified God (Minneapolis: Fortress Press, 1993).

59 Ibid., p. xii. 
the persons of the Trinity lays the groundwork for the relationship between God and humanity. However, he suggests that this unity is achieved through a tragic disunity when the Father tragically abandoned the Son on the cross. The Son and Father experienced mutual forms of separation-the Son suffered forsakenness by the Father, and the Father in turn experienced the anguish of forsaking the Son. At the cross the 'Fatherlessness of the Son is matched by the Sonlessness of the Father. ${ }^{60}$ However, in this process, according to Moltmann, the Father and Son were unified in the Spirit. Moltmann argues, 'what happened on the cross was an event between God and God. It was a deep division in God himself, in so far as God abandoned God and contradicted himself, and at the same time a unity in God, insofar as God was at one with God and corresponded to himself.' 61 The hope that ensues through the resurrection of the Son and the sending of the Holy Spirit therefore emerges directly from the unspeakable suffering and torment of the triune God in the event of the cross. Hence, the experience of being a human created in the image of God reflects the dynamic transformation from suffering to hope which was really experienced by the crucified and resurrected God. God's suffering is therefore not only an act of divine love for humanity, but also the means through which humanity experiences movement towards participating in the eschatological joy God intends for creation. Moltmann frames the imago Dei as humanity's eschatological destiny, a process that is both a present and unrealized promise. As he writes, 'the human being's likeness to God appears as a historical process with an eschatological termination that is not a static condition. ${ }^{62}$

Moltmann's narrative of the suffering God, however presents certain doctrinal challenges for classical theists who historically affirm the impassibility of God. Central to the critique is the extent to which God intrinsically participates and divinely takes up human suffering such that God ceases to be a God of omnipotence and worship as understood by historic Christian orthodoxy. That is, there is insufficient account taken of God's transcendence. Rather than transcending creation, God meets humanity on their limited terms, most notably through their suffering. In his effort to develop a more intimate relational imago Dei, Moltmann arguably defined God's relationship with creation in terms of human experience, rather than to focus on an all- embracing image of God whose overabundant love is extended to all people through Christ. In his critique, Robinson (2011) argues that 'whereas we do see our divine destiny in

\footnotetext{
$60 \quad$ Ibid., p. 243 .

61 Ibid., p. 244 .

62 Moltmann, God in Creation, p. 227.
} 
the movement from suffering to hope there is insufficient space of us to relate to God as something other, greater, more perfect than ourselves. ${ }^{\prime 63}$

Critiquing Moltmann's rejection of divine impassibility, however, should not invalidate his primary objective to develop a more contemporary narrative of the cross that speaks to God's involvement in the passion of Christ-apart from which divine solidarity with and entering into human suffering are mere empathetic gestures. ${ }^{64}$ Underlying Moltmann's polemic against the concept of a God who cannot suffer is his strident assertion that God cannot be passively uninvolved in human suffering. As God's image bearers, human beings' lived experiences on earth therefore mirror an eschatological pilgrimage from suffering towards hope, which is exemplified by the dialectical Triune fellowship. Just as the triune God experienced tragedy and suffering followed by restoration and hope, humanity also searches for and experiences hope amid the everpresent realities of despair. Moltmann's doctrine of the imago Dei is therefore grounded on God's solidarity with human suffering that culminates in eternal hope through the resurrected Christ. God does not passively sympathize with suffering from a distance, but identifies with and is affected by various forms of suffering. It is precisely within this context of necessary suffering that emerges an eschatological movement towards hope. The transformation of suffering to hope is the centerpiece of Moltmann's model of the imago Dei.

For Moltmann, the cross and resurrection necessarily stand in absolute contradiction to each other-straddling death and life; the godforsakenness and glory of God. ${ }^{65}$ This dialectical Christology of Christ who died and resurrected correspond to a dialectical eschatology in which the unfulfilled present contradicts the promised future of a new creation. The unfulfilled present, evident where there is social marginalization, poverty, and the oppressive abuse of power, completely contradict the eschaton upon which Christian hope rests. As such, the church actively revolts against the status quo of structural sins such that 'that there is no pleasant harmony between us and reality ... until the great day of the fulfillment of all the promises of God.'66 The ethics of hope, according to Moltmann, is grounded on humanity's likeness to God. That is to say, humanity fulfills its task and 'charge' as bearers of God's image and as part of the redemptive history written by God through Christ and enacted in the life of the believer by the Holy Spirit. ${ }^{67}$

63 Robinson, Understanding the 'Imago Dei', p. 149.

64 Bauckham, The Theology of Jurgen Moltmann.

65 Ibid.

66 Jürgen Moltmann, Theology of Hope (San Francisco: Harper Collins, 1991), p. 22.

67 Timothy Harvie, Jurgen Moltmann's Ethics of Hope: Eschatological Possibilities for Moral Action (Burlington, vT: Ashgate, 2009). 


\section{Implications: Persons Living with HIV and the Imago Dei}

I propose that Moltmann's doctrine of the imago Dei carries four important implications for addressing contemporary forms of HIV stigma. First, Moltmann's notion of the imago Dei reframes human identity in interpersonal terms. The image of God is not confined within the human individual as a possessive trait, but in human community, reflecting the trinitarian image. This represents a shift in understanding how I intrinsically bear God's image to how we bear God's image in our relationships with one another. Addressing HIV stigma is not simply recognizing the intrinsic worth and dignity of persons living with HIV. It involves enacting our fellowship with the Triune God and deeply engaging in acts of self-giving love by 'incarnating the same life-giving fellowship with others that was bountifully bestowed upon [us]. ${ }^{\prime 68}$ Faith-based HIV programming that focuses on increasing knowledge of HIV transmission and treatment has been promising, particularly among many communities of colour in the United States. A recent study of Chinese churches and temples in New York City, for example, found that being more knowledgeable about HIV transmission decreased stigmatizing attitudes towards PLHIV, which in turn increased support for institutional involvement in HIV programming. ${ }^{69}$ Moreover, among a growing number of African-American churches, HIV prevention and care messages are integrated with the gospel mandate to care for the least among us because we all bear God's image. ${ }^{70}$

However, application of Moltmann's doctrine of the imago Dei suggest that these approaches may prove insufficient unless awareness of HIV and recognition of individual worth are coupled with fostering, deep, self-giving relationships with PLHIV in community, where our likeness to God comes into being. How can the church create a social ethos that is reflective of the communal image of God-one that genuinely embraces diverse communities of PLHIV? Fostering and sustaining such communities, however, has been challenging for several reasons. First, discourse about HIV generally considers matters related to sexuality, morality, and substance use-issues that many churches are less inclined to address and integrate with their teachings. Secondly, HIV involvement potentially compromises the church's perceived moral standing and authority within their community and may alienate them from their constituents. Thirdly, church leaders and members alike have minimal knowledge about HIV and regard the epidemic as less relevant and beyond the scope

68 McDougall, Pilgrimage of Love: Moltmann on the Trinity and Christian Life, p. 162.

69 Kang et al., 'Influences of Stigma and Hiv Transmission Knowledge on Member Support'

70 Cosandra McNeal and Isaac Perkins, 'Potential Roles of Black Churches in HIV/AIDS Prevention', Journal of Human Behavior in the Social Environment, 15:2-3 (2012), 219-32. 
of their ecclesial mission. If the Trinitarian fellowship serves as a model for true human community, as Moltmann argues, are these barriers surmountable? What kind of communal ethos is cultivated such that it reflects God's trinitarian life? Of worthy consideration is to begin with existing congregational norms and attitudes, rather than to wait for unfettered acceptance and embrace of PLHIV. Based on his study of HIV-related activities in churches and temples in Los Angeles, Bluthenthal (2012) argues that 'HIV involvement is not (and need not be) a linear outcome of HIV stigma reduction: both may occur simultaneously, or one may occur before the other, dynamically affecting each other. ${ }^{71}$ As such it is important to consider a range of starting points for different churches with the goal of moving towards a congregational ethos of trinitarian fellowship or koinonia with diverse communities of PLHIV over time. This underscores the pivotal role particularly of clergy and leadership to carefully inculcate and visibly exemplify a trinitarian praxis of hospitality now and critically appraise the extent to which the larger Christian body tacitly excludes or overtly oppresses historically marginalized groups such as PLHIV or groups at higher risk of HIV infection. This brings us to consider the second implication of Moltmann's work.

Moltmann proposes a nonhierarchical ethic of social relations-a reciprocal giving and receiving that challenges any structural imbalance of power that renders one group unjustly treated. Moltmann specifically contested social hierarchies that unjustly denied humans 'those rights and duties which belong essentially to what it means to be truly human, because without their being fully acknowledged and exercised human beings cannot fulfill their original destiny of having been created in the image of God. ${ }^{72}$ Regardless of the theological positions taken within the church on certain practices and behaviour that have been historically (and narrowly) associated with HIV transmission (for example, intravenous forms of substance abuse, sexual intercourse outside of the context of marriage between one man and one woman), any form of social or moral hierarchy that unjustly devalues or mistreats persons or communities by passing judgment and condemnation is without 'defense' before God (Rom. 2:1). As such, if one's hermeneutical framework does not condone sexual conduct outside the marriage between a man and a woman, it does not principally preclude one to support equitable access to primary and preventive health care or adequate housing per se for female commercial or informal

71 Ricky Bluthenthal, et al., 'Attitudes and Beliefs Related to HIV/AIDS in Urban Religious Congregations: Barriers and Opportunities for HIV-related Interventions', Social Science and Medicine, 74 (2012), 1520-27 at 1525 .

72 Moltmann, On Human Dignity, p. 23. 
sex workers who use sex-for-money exchange to survive financially. Stated differently, a hermeneutic of what constitutes moral behaviour should never be grounds to enact or perpetuate stigma of any form.

Trinitarian fellowship, according to Moltmann, is nonhierarchical and leaves no room for dominion or subjugation of others. Since humanity fulfills their destined purpose as the imago Dei by freely loving in the manner of the triune God, true human fellowship therefore implies what MacDougall (2005) describes as 'radical equality' ${ }^{73}$ For Moltmann, the human being's likeness to God is present in relationships with all of creation, across economic, social, political, and personal spheres. Within community, these relationships are equal such that 'the three Persons are equal; they live and are manifested in one another and through one another. ${ }^{74}$ However, the construction and reification of current social hierarchies perpetuate the domination of majority groups which breed and sustain the stigmatization of PLHIV-most notably among those who belong to socially marginalized groups such as women, persons of colour, MSM, commercial sex workers, and injection-drug users. If misuse of social, economic, and political power undergirds the enactment and perpetuation of stigma towards PLHIV, how can the established church advocate against unjust domination of one group over another, and in doing so, fulfill her eschatological destiny as God's image bearer? Given the growing prevalence and incidence of HIV infection among African-American and Hispanic women, and MSM living in economically disadvantaged regions in the United States, it is arguable that HIV stigma is perpetuated by individual and structural systems that exert considerable power over these sub-groups based on race, gender, and socioeconomic status. How has the church prophetically addressed (or reformed) broader socio-political forces that unjustly avail resources and privilege to select groups, and in doing so perpetuate relationships that stigmatize and discredit PLHIV and their communities?

As North American churches position themselves more strategically in public health practice and policy discussions about global HIV care and prevention, it remains critical for them to reframe HIV as both a biomedical and biosocial problem that persist particularly among groups historically disadvantaged by race, gender, or economic standing. ${ }^{75}$ As such, it is timely for faith-based HIV

73 McDougall, Pilgrimage of Love, p. 158.

74 Moltmann, The Trinity and the Kingdom.

75 Refer to Hickel (2012) for an excellent analysis of how high HIV prevalence in Swaziland has arguably been due to declining rates of economic growth, formal employment and agricultural productivity have led to labour migration and transactional sex among poor households. 
programming to consider concerns of food security, maternal-child health, sustainable agriculture, and immigration/migration-because in doing so they begin addressing some of the structural inequalities in which HIV stigma festers and propagates. It is noteworthy that Wheaton College's theological statement on HIV states that 'Because we recognize that brokenness fractures all facets of human life, including the physical, spiritual, psychological and social, we seek to stand with those whose bodies and spirits have been devastated by disease and suffering, focusing not only on the pandemic itself but also on the issues that exacerbate it. ${ }^{76}$

This necessitates creatively collaborating across existing programming that may not necessarily target PLHIV per se, but recognizing that the secondary and perhaps tertiary programmatic outcome would be the mitigation of HIV stigma. A notable organization that exemplifies such an approach in Delhi is Evangelical Fellowship of India Commission on Relief (E FICOR). Established in 1980 to partner with churches in India to address issues of injustice and poverty and to facilitate communities towards wholistic transformation, EFICOR strategically prioritizes food security, climate change adaptation, disaster management, maternal-infant health, and HIV/AIDS. In addition to HIV prevention and care programming, for example, EFICOR's community mobilization initiatives with local church leaders, work with farmers to enhance agricultural productivity (thereby reducing migration from farming villages), and development of Village Development Committees to strengthen local leadership to secure government resources and to advocate for equitable treatment, particularly for vulnerable members of their communities - all address critical facets of socio-political systems that constrain assets and stagnates agency among PLHIV. Although the proximal goals of these initiatives are not to reduce HIV stigma per se, it critically addresses the structural context in which stigma acts and thrives. This brings us to the third implication of Moltmann's social imago Dei.

Moltmann's narrative of the cross underscores the importance of solidarity and participation with multifaceted forms of suffering experienced by PLHIV - not just challenges related to HIV illness. In the event of the cross, suffering is not extraneous to God, but is expressed in the grief of the Father and Godforsakenness of the Son. Moreover, Moltmann frames the God of the cross within social and political spheres. That is to say God's experience bears on all areas of civic life. It is this God in whose image humans bear-a God

76 Wheaton College, 'HIV/AIDs: A Biblical and Theological Response', Wheaton College, (2007), para. 16, <http:www.wheaton.edu/Stewardship/HIV-AIDS-Statement > [accessed 2 July 2014] (my italics). 
who suffers for and with people who contend with marginalized treatment of various forms. Understanding structural forms of HIV stigma necessitates engaging the messy intersections between HIV and social group affiliations. Stated differently, co-occurring stigmas intersect with each other including ones based on race/ethnicity, sexual orientation, gender, immigration, incarceration, commercial sex work, and illicit drug use. As such, due to cultural proscriptions against HIV-illness and sexual orientation in communities of colour, a Latina who is lesbian will likely experience HIV-related stigma differently from a Latina who is heterosexual and perinatally acquired HIV at birth.

A common discourse within the church is the harmful distinction made of persons who innocently acquire HIV through maternal-infant transmission or iatrogenic means (for example, blood transfusion), and those who acquire HIV through less innocent behavior (e.g., high-risk sexual practices and injectiondrug use). ${ }^{77}$ The rhetorical omission of innocence excludes and stigmatizes certain groups affected by HIV, where a person's sexual practices and substance dependence become the stigmatizing mark. In several communities, most notably among African-Americans, proscriptions against homosexual behaviour have heightened fear of HIV-serostatus disclosure among African American MSM largely due to potentially raising public suspicion of their sexual orientation - which carries a far more stigmatizing mark than HIV. ${ }^{78}$ Given how HIV-related stigma intersects with other forms of stigmatization experienced by PLHIV, it is important to consider how North American churches can mitigate stigmatizing attitudes and behaviours towards persons living with HIV who identify as lesbian, gay, or bisexual, or engage in high risk sexual or injecting drug use behaviour.

An approach worthy of consideration is for North American churches to cast a broader ministerial net that extends beyond children orphaned by HIV in African countries. Mass-marketed memoirs such as Kay Warren's Dangerous Surrender or Lynne Hybel's' Nice Girls Don't Change the World that recount the suffering of women and children victimized by H IV have been extraordinarily successful in mobilizing North American churches to care for the least among us in the African continent through the transformative properties of sentimental faith. ${ }^{79}$ The HIV/AIDS Initiative at Saddleback Church, for example, was

77 Gill Green, 'Evangelical Leaders and People with HIV', AIDS Care 9:6 (1997), 715-26.

$7_{8}$ Angelique Harris, 'Sex, Stigma, and the Holy Ghost:The Black Church and the Construction of AIDS in New York City', Journal of African American Studies, 14 (2010), 21-43.

79 Anthony Petro, 'After the Wrath of God: American Christians and the Biopolitics of AIDs', paper presented at the annual American Academy of Religion meeting, (San Francisco, CA, October 13-16, 2011). 
influential in lobbying for abstinence-based HIV prevention measures to be included in George W. Bush's important President's Emergency Plan for AIDS Relief (PEPFAR) which has allocated over 30 billion dollars towards global HIV care and prevention initiatives since 2004. The momentum set by these important faith-based milestones should be applauded and not cynically dismissed. Yet the looming concern is the extent to which personal narratives of individual suffering and the transformation of select groups delimits institutional policymaking that aid individuals rather than support efforts aimed at broader structural reform that benefit communities affected by HIV at-large.

Finally, the imago Dei implies that God's relationship with humanity in the present world ushers hope and meaning. Emerging out of separation and suffering at the cross, according to Moltmann, is new life and hope of the resurrection. When human beings recognize the potential of incarnating their fellowship with God in individual, social, and institutional realms, they are able to engage deeper with more urgency and hope. As Moltmann writes in the Theology of Hope (1991):

Hope finds in Christ not only a consolation in suffering but also the protest of the divine promise against suffering ... That is why faith, wherever it develops into hope, causes not rest but unrest, not patience but impatience. It does not calm the unquiet heart, but is itself this unquiet heart in a man. Those who hope in Christ can no longer put up with reality as it is, but begin to suffer under it, to contradict it. ${ }^{80}$

It is arguable that the unprecedented decreases in global HIV mortality and morbidity due to advances in antiretroviral medication treatment and public health policies have offered hope for innumerable PLH IV. We are ushered into an era where HIV/AIDS is now considered a chronic rather than a terminal condition, evidenced by the growing number of adults living with HIV who are 50 years of age or older in the United States. ${ }^{81}$ However, for the growing number of PLHIV who contend with the challenges of institutional racism, gender-based violence, and poverty in addition to living with a chronic medical condition that continues to be shunned in many communities, hope remains elusive. The 'full plate syndrome,' described by Morales and Bok (1992) ${ }^{82}$ as the

8o Moltmann, Theology of Hope, p. 21 (original italics).

81 Judith Levy et al., 'HIV/AIDS Interventions for Midlife and Older Adults: Current Status and Challenges', JAIDS, 33: Suppl 2 (2003), S59-67.

82 Julio Morales and Marcia Bok, 'AIDs with a Cultural Context: A Perspective', in J. Morales and M. Bok, eds, Multicultural Human Services for AIDS Treatment and Prevention: Policy Perspectives and Planning (Philadelphia, PA: Haworth Press, 1992), pp. 1-12 at p. 4. 
competing demands of persistent poverty, racism, and HIV, raises the conundrum of determining how these sobering realities uniquely and collectively shape the formation of hope for communities affected by HIV ... and for those who work alongside them. The reality of living with a stigmatized illness under the daily grind of structural realities that create and recreate iterative forms of stigma often tempers one's expectations and definitions of progress. This is especially pertinent since outcomes of structural interventions are generally distal and not immediately measurable. A Christian ethic of hope, however, scaffolds our messy engagement with these realities, with the anticipation of the promised new creation. Embracing hope in the risen Christ positions believers to accept and tolerate the mounting challenges of contradicting the unfulfilled reality and charting towards the promised future.

In Theology of Hope, Moltmann reinvigorates our notion of hope in the resurrection of Christ as an impetus to actively engage and creatively protest against any form of human suffering - rather than passively seeking solace in a domesticated eschaton. As imago Dei, human beings not only respond in love to God's gift of fellowship but are blessed and charged with extending this fellowship with all of God's creation. As Moltmann writes, human being's likeness to God is 'both gift and charge, indicative and imperative. It is charge and hope, imperative and promise. ${ }^{83}$ Quite a charge indeed.

\section{Conclusion}

As we approach the third decade of HIV, the stigma of a hastened death sentence has fortunately abated in the Global North. Unprecedented advances in antiretroviral treatment coupled with progressive public health policies have created a rippling Lazarus effect, where many persons living with HIV now navigate the unexpected terrain of living with a chronic manageable condition-rather than dying from a terminal illness. However, since HIV transmission historically thrives mostly in communities that have been marginalized based on race, gender, social class, and sexual orientation, this paper proposes that HIV-stigma cannot be singularly framed as an intrinsic spoiled identity based on illness. The fear of contagion and the incurability of H IV that persist, particularly in the Global South, often co-exist with discrediting attitudes most notably towards women, ethnic and sexual minorities, the poor, commercial sex workers, and injection drug users. As such, efforts to reduce or mitigate the destructive vestiges of stigma that linger must address social relationships that are embedded in socio-economic and political structures that insidiously

Moltmann, God in Creation, p. 227. 
exclude and devalue these groups. Moltmann's doctrine of the social imago Dei provides an important framework to challenge and guide how Christians begin addressing this complex web of factors. His bold doctrinal recasting of the imago Dei suggests that human dignity is discovered and expressed in relationship with others. Humanity bears the image of the mutually supporting persons of the Trinity. A relationship that is characterized by radical equality that fosters participation in all facets of suffering - an impetus and charge that is set by the hope established by Christ's resurrection. It is this divine imago that incites us to deliberately contradict identities that are spoiled by HIV with one that is of unspeakable worth and hope. ${ }^{84}$

84 Author Note: The author acknowledges Cynthia Neal Kimball's and Jeffrey Barbeau's commentaries on drafts of the manuscript 